\title{
Natural disaster and informality (re)production in Chile
}

\author{
Irina Tumini ${ }^{\mathrm{a}, *}$, Angela Poletti ${ }^{\mathrm{b}}$ \\ ${ }^{a}$ Madrid, Spain \\ ${ }^{\mathrm{b}}$ Politecnico di Milano, Milan, Italy
}

\begin{abstract}
This paper addresses the crucial need to gather more in-depth knowledge on the social construction of hazard by exploring risk exposition in informal settlements. The confluence of certain hazard conditions and inherent or contextual vulnerability configurations increases exponentially the risk of damages in the case of calamitous events. This suggests that the eradication of urban informality may contribute to reduce the vulnerability to natural hazards as well. This study proposes the use of the Geography of Opportunity and the Basic Liveability approach to understand the processes triggering the (re)production of informality and, more specifically, the factors driving settlements localisation into hazard-exposed areas. Two Chilean cities have been taken as case studies, as they constitute a paradigmatic example of social construction of hazard in Latin-America. The pro-posed case studies allow us to analyse the residential deficit and informality eradication policies in Chile. As a result, we observed that informal settlements are strategically located in relation to the structure of metropolitan opportunities, but the trade-off for this is the occupation of marginal and hazard-exposed areas. The conclusions give some recommendations in order to support policymakers to provide more comprehensive urban planning and risk management strategies to face future challenges, involving issues as urban poverty, social inequality and housing policy in addition to aspects related to pure hazard exposition.
\end{abstract}

Keywords: Hazard, Vulnerability, Risks, Urban informality, Geography of opportunity

\section{Introduction}

Several scholars point out the "un-natural" aspects of natural events, which cause damages to human settlements (Cardona, 2003, chap. 3; Olivera \& González, 2010; Rodríguez, 1990). Often, the impact of a natural event on communities increases due to un-natural reasons such as lack of preparedness, uncontrolled development, environmental deprivation or low capacity of communities to cope with disasters. In general, this is due to all those human activities that contribute to the increase of urban vulnerabilities and socio-economic inequity.

The impact of natural events on society, economy or the environment may vary from one region to the other and may certainly derive from community vulnerability. In the Fifth Assessment Synthesis Report, the IPCC (2014) highlights that uneven development processes shape differential exposure to risks. People who are socially, economically, culturally, politically, administratively or otherwise marginalised are especially vulnerable to natural threats (IPCC, 2014). According to the Sendai Framework for Risk Reduction (2015), disasters significantly impede progress towards sustainable development. Evidence indicates that exposure of people and assets in all countries has increased faster than vulnerability has decreased (UNISDR, 2015).

In this context, research on vulnerability refers to the concept of "social construction of hazard" as a central part of the disaster process, in which vulnerabilities of affected communities are shown to exacerbate the incidence and the intensity of the effects of natural events (Bankoff, 2004). The confluence of certain hazard conditions and demographic, and social and economic vulnerabilities increases exponentially the risk to suffer damages in case of calamitous events (Argüello-Rodriguez, 2004; Olivera \& González, 2010). Paradigmatic examples of this phenomenon are informal settlements and deprived neighbourhoods, which are especially affected by natural events.

Currently more than one billion people live in informal settlements and this number, according to available forecasts, should duplicate by 2030. The situation is particularly problematic in developing countries, where most of the population growth happens, encouraging the development of areas of informal and unauthorised building. Such statistic makes the issues of slum a problem for urban risk management as well as for future urban development (Olthuis, Benni, Eichwede, \& Zevenbergen, 2015; Soyinka \& Siu, 2018, pp. 1-14). Therefore, fight against urban informality should become a priority at national and local level, because of a double benefit, namely the reduction of urban vulnerabilities, achieved by readdressing social-economic inequity, and the improvement of disaster risk management.

With this in mind, this research aims to raise awareness on the link

Received 15 October 2018;

Received in revised form 15 July 2019;

Accepted 10 October 2019

Available online 01 November 2019

* Corresponding author.

E-mail address: irina@ecometro.org (I. Tumini). 
between the social construction of hazard and urban informality growth, through an understanding of the processes of informal settlements localisation within a urban area, especially focusing on the aspects addressed by land use and urban planning. This study will show how poor households seek a strategic location within the downtown of their city and how that is possible only by occupying residual spaces, such as hazard-exposed areas. Our research methodology is based on the Basic Liveability (Habitabilidad Básica in Spanish-HaB) approach, which sees recognition of the Geography of Opportunity (GOp) as the main driver of urban informality re-production.

The Metropolitan area of Concepción (Chile) is considered as a case study. Because of their peculiar geographical conditions, Chilean cities are subjected to several risks: earthquakes, tsunami, volcanic eruptions, floodings, fire, landslides, etc. During the last twenty years, and after signing the Hyogo Framework for Action (2005-2015), the Government has promoted actions to develop the comprehensive risk management, which involves the reduction of threats impact as well as the improvement of society's ability to recover from disasters. At the same time, with reference to housing deficit reduction, the $C$ hilean social housing policy is the most successful in Latin America. Nonetheless, urban informality has increased during the last years. Thus, the fight against urban informality and the reduction of vulnerability to natural threats are critical for future social and economic development of the Country (Beytía \& Correa, 2013).

Paragraph two will address the issues relative to urban informality in Chile; paragraph three will describe the methodology of the study based on Geography of opportunity and Basic Liveability (HaB) and its application to the case studies; paragraph four will discuss the results; the fifth and last paragraph will lay out our conclusions.

\section{Vulnerability, construction of risk and urban informality}

Generally speaking, vulnerability means a potential for loss (Cutter, S. L., Boruff, B. J. and Shirley, 2003). The International Strategy for Disaster Reduction (UNISDR) defines vulnerability as: "The conditions determined by physical, social, economic and environmental factors or processes, which increase the susceptibility of community to the impact of hazard" (UNISDR, 2004). Thus, vulnerability represents the system or community's physical, social, economic, political and/or cultural susceptibility to suffer damages as result of an hazardous event (Birkmann, 2006). With regard to social vulnerability, some authors (Brooks, 2003; Ciurean, Schröter, \& Glade, 2013; Cutter, Boruff, \& Shirley, 2003) describe it by a set of characteristics of population such as: initial wellbeing, livelihood and resilience, self-protection, social protection, social and political networks, etc. This definition shows that the type of hazard only partially determines the concept of vulnerability. Social conditions such as deterioration or precariousness drive the capacity of a community to respond to negative impacts due to hazard (Birkmann, 2006).

To study the vulnerability of human settlements, Cardona (2003), chap. 3 and Bankoff (2007) have introduced the concept of "social construction of hazard". This concept is based on the observation that the impact of disaster depends on the resilience of households and communities to natural events. The resilience is defined as the capacity to absorb, to cope with and recover from disaster. It is also related to the level of resources and the ability to use them to deal with the adverse consequences of hazard (Arouri, Nguyen, \& Youssef, 2015). Indeed, the hazard is constructed socially: it is the materialisation of socio-economic fragility, physical degradation and lack of resilience. Therefore, the disaster is not an isolated event, but the result of a process which should be studied to individuate driving forces behind it.

Several scholars (Bankoff, 2004, 2007; Miranda Sara, Jameson, Pfeffer, \& Baud, 2016; Olthuis et al., 2015) highlight that local communities have a wide diversity of risk perception and risk tolerance. Specific risks are prioritised and/or normalised within the economic, social or physical context, and they affect the reaction and the knowledge gathered and used to face natural events. In the case of informal settlements, communities prioritise immediate needs (mainly socioeconomic concerns) instead of being worried about long-term hazards. Often, people that have undergone the same disasters again and again may become used and indifferent to them. In some cases, exposed communities adopt coping mechanisms in order to mitigate the impact of a disaster and to tolerate the constant presence of hazards. The "normalisation of the threat", may be a significant factor influencing cultural aspects, knowledge and behaviours of communities and, in some way, contribute to the construction of hazard (Bankoff, 2004; Miranda Sara et al., 2016).

Olivera (2010), in her studies about post-disaster reconstruction in Cuba, provides a framework for the "Risk Re-production cycle" during post-disaster reconstruction. Her research has proven that reconstruction programmes which are purely oriented to housing-rebuild, do not mitigate pre-existent vulnerabilities. Hence, the community is not able to improve its preparedness and adaptability to face future risks and it will be affected again by the next adverse event (Olivera \& González, 2010; Olthuis et al., 2015).

Other authors speak about pre-disaster or ex-ante management as a set of mitigation measures oriented to reduce communities' vulnerabilities to face natural disaster. Ex-ante disaster management is, in general, more cost-effective than ex-post disaster management but government ex-ante efforts may be weak, and poor people cannot afford expensive mitigation measurements (Sawada \& Takasaki, 2017). This is even more often true in developing countries, where built environment is more vulnerable due to overcrowding, poor quality of housing, precariousness, low income and anthropic risk. Thus, houses provision and informality eradication policies may affect the existent vulnerabilities and thereby the social construction of risk.

The exposition of vulnerable people to natural risk "may create a feedback loop, in which poor households have no choice but to settle in at-risk zone and therefore face increased challenges to escape poverty"(Winsemius et al., 2018, p. 6). Studies on flood risk in cities of developing countries show that poorer people are more likely to live in at-risk areas because of the lower housing price in exposed zones (Arouri et al., 2015; Winsemius et al., 2018). Nevertheless, this study aims to show how focusing only on the link between household income and settlements in exposed areas does not adequately reflect the complexity of the problem at hand.

\subsection{Urban informality and relative features in Chile}

The colonisation of informal settlements in Chile started around the 1930 in Santiago, when the crisis of the saltpetre mines resulted in a massive immigration flow of job seekers. Instead of finding residential solutions in suburban areas, people started to occupy marginal areas near the city downtown. As time went by, these spontaneous settlements became more organised and it became clear that the settlers intended to keep occupying such locations. During the Allende government (1970-1973), in order to provide a temporary solution to the housing deficit, the government released wooden hut settlements on free plot to create the so-called campamentos de emergencia. During this short period of time, marginal sectors of population reconquered the centre of the city. The military government (1973-1990) stopped this policy, demolishing the campamentos de emergencia because they were considered loci of resistance to the regime. Then, inspired by neo-liberal principles, the regime designed a new social housing policy, based on subsidising the low-income households for home purchase, while the private sector would provide housing solutions (Castro, Ibarra, Lukas, Ortiz, \& Sarmiento, 2015; Gilbert, 2004). During the 1970s, the government built social houses in suburban areas located in the first ring. Since 1985, due to the growth of cities and the consequent increase of land prices, the real estate market could not support this low-income investment. Therefore, new social housing was built far from the city centres, without public utilities, services and connection. Nevertheless, in 1993 the Inter-American Development Bank and the U.S. Agency for 
International Development (USAID) defined the Chilean housing model as the "best practice" because it included three elements for development: "private market provision, explicit targeting of the poor and transparency" (Gilbert, 2004, p. 15).

In the last decades, alongside the housing deficit policies, the national and local government have started a progressive consolidation process of informal settlements, including infrastructure improvement and formalisation. Nevertheless, several settlements have been regularised without changing their fragile socio-residential characteristics in a fundamental way, which seems to have amplified their vulnerability to hazard (Castro et al., 2015).

The official Chilean definition for informal settlements, provided by the Ministry of Housing and Urban Planning, (MINVU in Spanish acronym), defines the campamentos, or settlements, as mainly urban areas, constituted by more than eight families, inhabiting land owned irregularly, lacking coverage of at least one of the three basic utilities (i.e. electricity, running tap water, or a sewage system), whose housings are grouped and contiguous (MINVU, 2011). Thus, this definition is useful and complex (Castro et al., 2015) but does not consider vulnerability and hazard exposition.

\subsection{Institutional actions and (re)production of urban informality}

The new democratic Government became aware of the problem and promoted different policies and programme for the massive eradication of slums. The MINVU was given the task of elaborating the National Programme for Poverty Reduction, which provides two types of interventions:

I. The "resettlement out-of-site", referring to the resettlement on social houses, including both of the following solutions: block housing or individual self-built houses. The social housing programme supports the housing demands, through facilitated credit (by vou cher) to low income families, while the private real estate market is in charge to provide suitable housing solutions (Pérez-Iñigo González, 1999; Rodriguez \& Sugranyes, 2004). This policy, started under dictatorship, continued under the following governments, and in 1984, with the DS $62 / 84$, the government transferred to the private sector the competence for building social housing, including the purchase of land. In addition, this law allowed a lowering of the standards for urbanisation and minimum quality of social housing. This regulatory modification produced changes in price, land use and a dramatic suburbanisation, especially involving the most vulnerable sectors of the population. The result was the creation of new neighbourhoods with lower urban standards, and an exacerbation of inequality and spatial segregation, under the guidance of the institutions. Many people who live in these neighbourhoods cannot have access to employment and urban services such as education and health services (Castillo-Couve, 2012; Castro García, 2005; Pérez-Iñigo González, 1999; R odriguez \& Sugranyes, 2004). As a consequence, the different governments after dictatorship have delegated to the private sector all decisions on how and where to build the houses for the poor. This solution does not guarantee housing quality and does not safeguard the needs of most vulnerable section of the population. (Castillo-Couve, 2012; Pérez-Iñigo González, 1999).

II. The resettlement "in-site" promoting the slum upgrading. The implemented measures are mainly oriented to improve housing quality, basic services such as potable water, sewerage, paved streets, etc. and land regularisation. The Government has adopted two main procedures: a) the resettlement in new dwelling solution by providing voucher to build (or self-build) a new house in the same plot or b) the upgrading of the urban services. ${ }^{1}$ In the last case, the programme provides financial

\footnotetext{
${ }^{1}$ During the time, the Ministry of Housing (MINVU) promote several programmes. Among them: Chile Barrio, Pavimentos participativos, Quiero mi Barrio, Mejora Viviendas y Barrios, etc (http://www.minvu.cl/opensite_det_ 20150901142947.aspx, last visit May 17-2017).
}

and technical resources to community for public spaces recovery and amenities improvement after a process that involves citizen participation. The measures focus on social and urban vulnerability mitigation but only in few cases the interventions have been oriented towards risk vulnerability reduction.

\section{Methodological framework}

The goal of this work is to understand the site selection for informal settlements (campamentos) in Chilean cities using the two theoretical approaches of Geography of Opportunity (GOp) and HaB, because they allow to individuate a link between urban structure and opportunity structure, that is a priority for informal settlement localisation.

\subsection{Geography of opportunity (GOp) and basic liveability (HaB)}

The GOp is a useful framework for studying inequalities within metropolitan areas. The opportunity refers to the "structure of metropolitan opportunities" as well as to the "set of perceived opportunities". Both have a great influence on individual decisions. Essentially, metropolitan opportunity deals with two main issues:

a. Markets and institutions having equivalent resources and policies across metropolitan areas.

b. Households having equal capacity to reside specifically where they deem the market and institution more desirable.

According to Galster \& Killen (1995), key elements of metropolitan opportunity structure consist of a comprehensive set of physical, social, economic, political and institutional conditions. Among such conditions there are housing (quality and accessibility), mortgage, local, political and crime justice services, labour market, educational, health and social services systems. All these individual elements are bound in immensely complicated interrelationships.

Of course, opportunity structure and perceived opportunity vary across individuals, due to personal characteristics, such as family background, social networks etc. However, in general, "people could sort themselves spatially to take advantage of what they perceived as the best localisation" (Galster \& Killen, 1995, p. 24). This indicates, for instance, a localisation that facilitates access to labour market, proximity to educational and health services or promotes the maintenance of social networks. Conversely, inequality among neighbourhoods generates urban segregation and social disparity, and affects the citizens' accessibility to the housing and labour market (Osypuk \& AcevedoGarcia, 2010).

The GOp is a framework used to study urban inequality and racial segregation (Galster \& Killen, 1995; Osypuk \& Acevedo-Garcia, 2010). Its application to urban informality in this work is supported by the theory of basic liveability (HaB), developed by ICHAB-UPM (Perea Moreno, 2015).

The $\mathrm{HaB}$ approach tries to provide a quantification of minimum conditions to fully exploit personal and collective ability to achieve individual or communitarian goals. Below this level, the habitability is precarious or inadmissible. According to this principle, liveability depends on physical and non-physicals conditions. Physical conditions are the architectural and urban settings, while social factors are considered non physicals conditions. In other words, the concept goes further than the simple satisfaction of the basic need for shelter, involving other social, economic and personal aspects. From this point of view, site selection indicators are closely linked to urban and metropolitan structure (Gesto, 2015).

On these premises, this study has considered the GOp of two case studies in relation to the location of the campamentos, drawing conclusions accordingly. Geographic Information Systems (GIS) technology has allowed us to elaborate data about informal settlements location, land use and hazard exposition. Data have been provided by the 
Table 1

Geography of opportunity framework.

\begin{tabular}{|c|c|}
\hline Indicator & Description \\
\hline Distance from Nursery (m) & $\begin{array}{l}\text { Average distance from campamento to nursery. The nursery service supply allows women to } \\
\text { engage in work activities. }\end{array}$ \\
\hline Distance from Primary School (m) & Average distance from campamento to Primary School. \\
\hline $\begin{array}{l}\text { Distance from Secondary School } \\
\text { (m) }\end{array}$ & Average distance from campamento to Secondary School. \\
\hline $\begin{array}{l}\text { Distance from Healthcare centre } \\
\text { (m) }\end{array}$ & Average distance from campamento to public Health centre for primary health attention. \\
\hline Distance from Hospital (m) & Average distance from campamento to the Hospital for health attention and urgency. \\
\hline Distance from Fire Station (m) & $\begin{array}{l}\text { Average distance from campamento to the Fire Station, because it provides support during } \\
\text { emergencies. }\end{array}$ \\
\hline Distance from Police Station (m) & $\begin{array}{l}\text { Average distance from campamento to Police Station, because it provides public security } \\
\text { service and support during emergencies. }\end{array}$ \\
\hline Public Transportation (n) & $\begin{array}{l}\text { Number of Public Transportation line close to campamento. It provides information about } \\
\text { connectivity with downtown and other cities. }\end{array}$ \\
\hline Employment Source (ES) & $\begin{array}{l}\text { Labour market available close to campamento, which provides job opportunities for } \\
\text { settlement inhabitants. For instance, industrial activities, services, commerce, harbour, } \\
\text { fishing or touristic activities, etc. }\end{array}$ \\
\hline Land use & $\begin{array}{l}\text { Land use according to Municipal Urban Planning Zoning and representing the legal/tenure } \\
\text { condition of the area }\end{array}$ \\
\hline
\end{tabular}

Assessment levels

Optimum: $1 \mathrm{~km}$ (15 min walking)

Optimum: $1 \mathrm{~km}$ (15 min walking)

Optimum: $2 \mathrm{~km}$ (30 min walking)

Optimum: $1 \mathrm{~km}$ (15 min walking)

Optimum: $30 \mathrm{~min}$ walking or with public transport

Optimum: $30 \mathrm{~min}$ walking or with public transport

Optimum: $30 \mathrm{~min}$ walking or with public transport

№ of bus lines close to settlement (average distance to Bus stop $\leq 800 \mathrm{~m}$ )

Optimum: $4 \mathrm{~km}$ (1 h walking)
Ministry of Public Goods (Ministerio de Bienes Nacionales Infraestructura de Datos Geoespaciales), Municipalities of Talcahuano and Tomé and the Laboratory of Urban Studies of Universidad del BíoBio (LEU-UBB). The NGO TECHO has provided the information regarding the updated location of the campamentos that we considered. After representing available data on a map using GIS, it is possible to identify, for each settlement, hazard exposition and land use, and to calculate the Euclidean distance to services. Labour market sources and the quality and availability of public transportation was defined by onsite verification. Thanks to the assessment of indicators and the comparison with the optimum values, it is possible to describe the GOp of settlements.

The analytical framework focuses on factors relative to urban structure, such as accessibility to labour market or services proximity, which make the location more desirable for households. Specifically, in this work the analysis focused on the following elements:

\subsubsection{Accessibility to services}

The delivery of urban services, resources and facilities is a key component of the neighbourhood opportunity. Spatial inequality of the access to public education, health services, public transportation and urban security generate urban segregation that affects people's opportunity. For instance, the presence of a nursery service influences the incorporation of women into the labour market; the quality of primary and secondary schools affects the level of education; the availability of public transportation impacts people mobility (from/to work, school, etc.). The access to services and urban facilities can be assessed by their degree of proximity to their users. As a consequence, the access to education is assessed by Distance from Nursery, from Primary School, from Secondary School. Likewise, the access to health is evaluated by the Distance from Health centres and from the Hospital, while the distance from Fire-station and from Police Station are indicators of security services. The Public Transportation service is assessed according to the number of bus lines and the availability of other urban and metropolitan transportation systems. The observation scale of this indicator is the neighbourhood, and the distances are calculated from the campamento to the closest service (Nursery, School, Health centre, etc.).

\subsubsection{Accessibility to labour market}

The accessibility to labour/productive market is the first factor that influences the settlement localisation into a urban context. People in a subsistence economy cannot travel several hours to look for a job.
Therefore, slums lie near industrial, rural or fishing production centres. Women prefer to live near downtown, when they can work in services, handcrafts sale or informal commerce (such as street-food).

Furthermore, it must be emphasised that the informal settlements are often "spaces for home-based entrepreneurship" (Roy, 2011, p. 277). Actually, slums generally have a vibrant, self-organised economy, where people provide any kind of services and their house is often a laboratory for hand-made products (food, handicraft, etc.). Therefore, localisation into the urban area is crucial also to ensure the survival of this peculiar kind of entrepreneurship.

The accessibility to labour/productive market is represented by the Employment Source indicator, which is calculated by observing the proximity and connection (by public transportation) to industrial and commercial centres consistent with the Land Use Plan.

\subsubsection{The legal/tenure condition of area}

According to some authors (Castro et al., 2015; Fernandes, 2011), usually poor people select unbuilt areas where they can remain some years without constant threat of eviction. This is the case of public lots, derelict land or empty proprieties, such as protected land near railways, areas of environmental conservation, brownfields or risk-exposed areas.

An analysis of the Land Use defined by urban planning documents allows an assessment of the legal conditions of a given area. The Land use indicates the activity allowed on the area, such as its building index or constrains to construction, and, at the same time, it provides information regarding the integration of risk into urban planning, e.g., environmental protection requirements.

There is no single geographical scale for different components of neighbourhood opportunities. For instance, labour market is generally considered congruent with the metropolitan region, while public education may clearly vary within the same city. For the purpose of this work and according with $\mathrm{HaB}$ criteria for settlements site selection, the observation of GOp was limited to the neighbourhood level (see Table 1). The accessibility to resources and services is based on the concept of spatial relationship between the settlement and urban context (Gesto, 2015).

\subsection{Case studies description}

To understand the social construction of hazard, this paper presents the case studies of informal settlements located in Talcahuano and Tomé, two coastal cities of Biobío Region (Chile) (Fig. 1). The Region of Biobío is in the mid-south of the country, with almost two million 

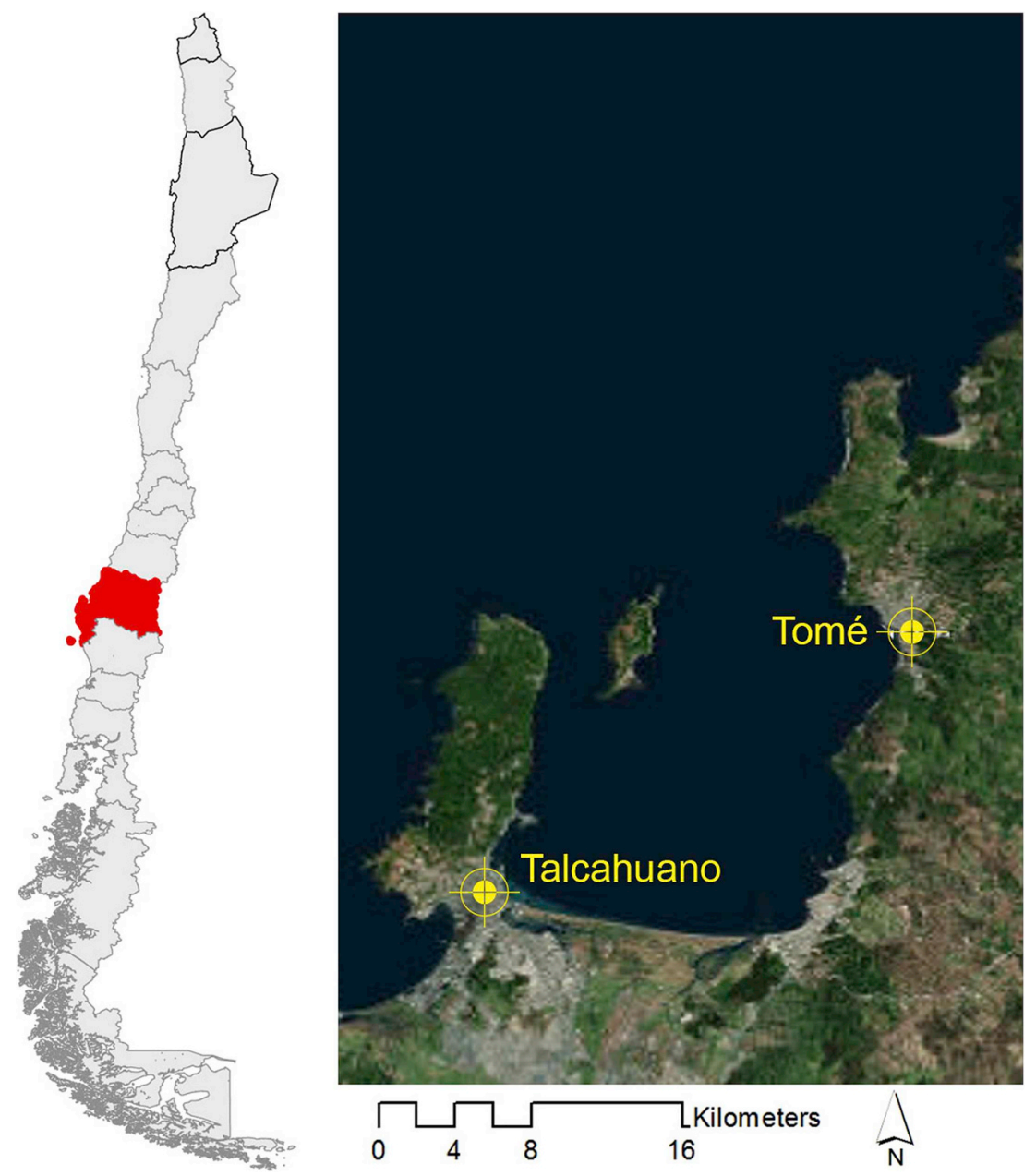

Fig. 1. Identification of case studies: Talcahuano and Tomé.

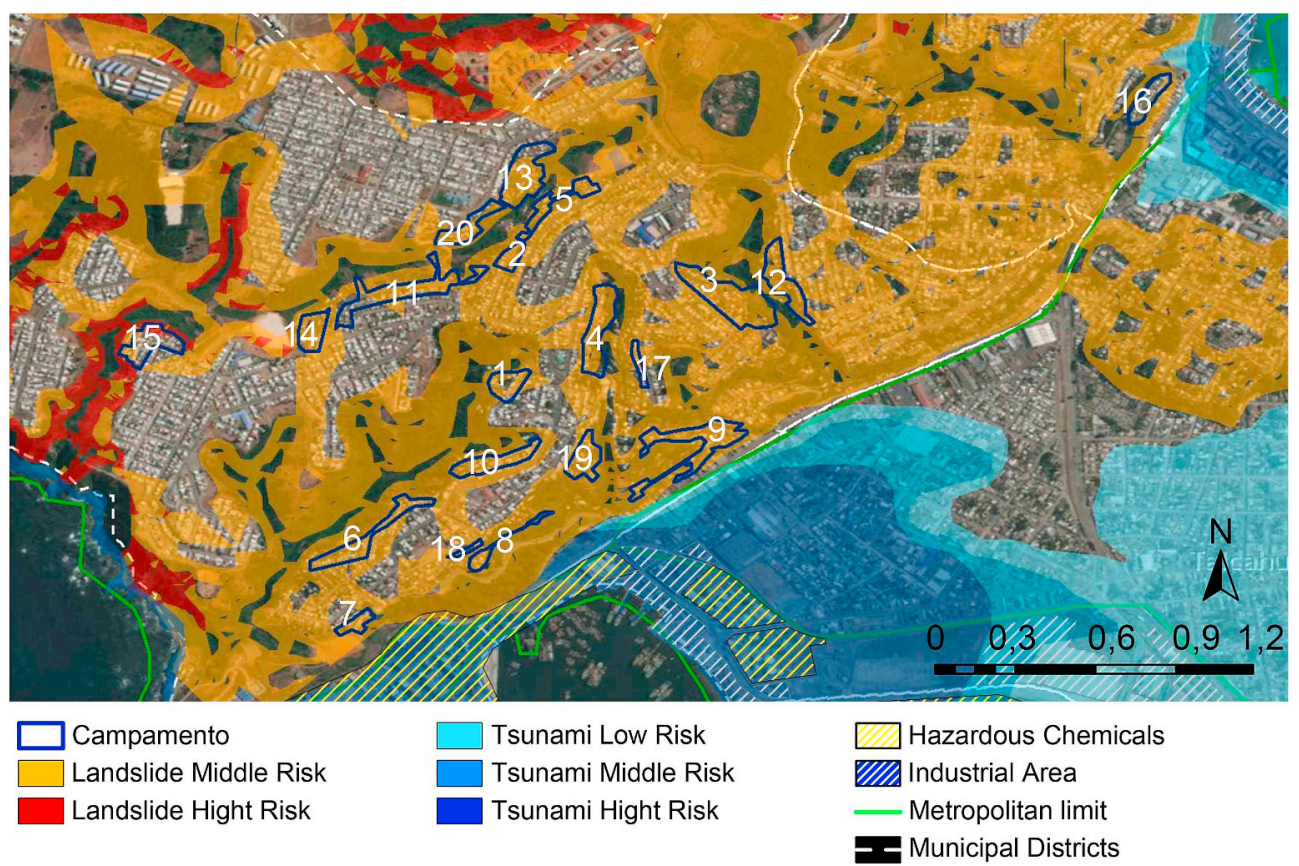

Fig. 2. Talcahuano Risk map and informal settlements. Source: Municipality of Talcahuano, Base-map: World Imagery Esri. 


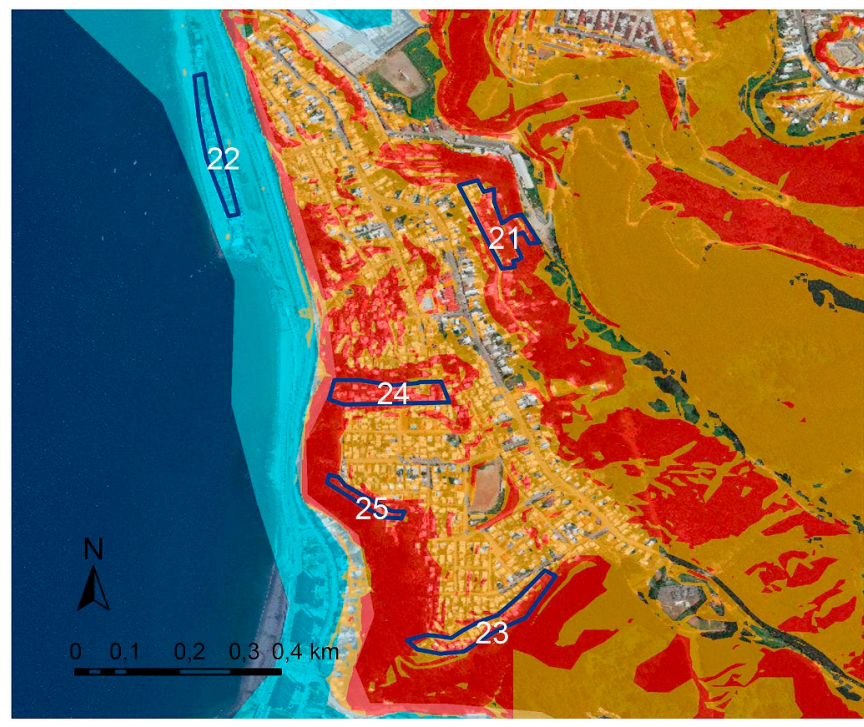

Campamento Landslide Middle Risk Landslide Hight Risk

Fig. 3. Tomé Risk map and informal settlements. Source: LEU-UBB, Base-map: World Imagery Esri.

inhabitants, and it is the second most populous region of Chile. The choice stems from various circumstances. First of all, after the Valparaiso Region (V Region), Biobío (VIII Region) is the region in Chile with the second highest number of informal settlements. According to data collected by TECHO, in the region of Biobío there are 132 campamentos, where 7.510 families live.
Second, throughout history, the cities of the Biobío region suffered several disasters caused by hydrogeological risks as flooding, drowning and landslide, forest fires as well as earthquakes that could cause tsunami and soil liquefaction and slipping. In 2010 an $8.8 \mathrm{Mw}$ earthquake with epicentre in Pelluhue, $60 \mathrm{~km}$ north of Concepción, affected several cities of the mid-south of Chile. The earthquake triggered a tsunami which devastated several coastal towns of Biobío, Tomé and the Talcahuano port among them. Additionally, in January 2017, a big fire threated the metropolitan area for several days. Due to the magnitude of both recurrent and non-recurrent risks exposition, construction activities should consider risk exposition and integrate mitigation measures.

Third, after an earthquake and a tsunami on February 2010, the Municipalities of Talcahuano and Tomé have been involved in a complex reconstruction programme. The land use of cities has been upgraded introducing risk evaluation maps and specific regulations for exposed areas. In addition, Talcahuano, which has suffered severe damages due to tsunami, has created the first Chilean Office of Integrate Management of Natural Disaster Risk. Despite the improvements that have been accomplished with regard to Risk Management, and the opportunity offered by reconstruction activity to reduce urban vulnerabilities, today there are still several informal settlements located in unsafe areas.

The city of Talchahuano has about 250.000 inhabitants, mainly in its urban area, and is the most important harbour of the Region. The town is settled in the Tumbes peninsula, between the Bio-Bío and Andalien Rivers. Within the urban area, there are twenty campamentos, mainly located up the hill of peninsula, along the ravines, with 817 families living there.

The town of Tomé is a coastal city located north of Concepción bay. With more than 52.000 inhabitants, the economy of the city is mainly based on the textile and fishing industries. The town counts 5 campamentos, where 183 families currently live.

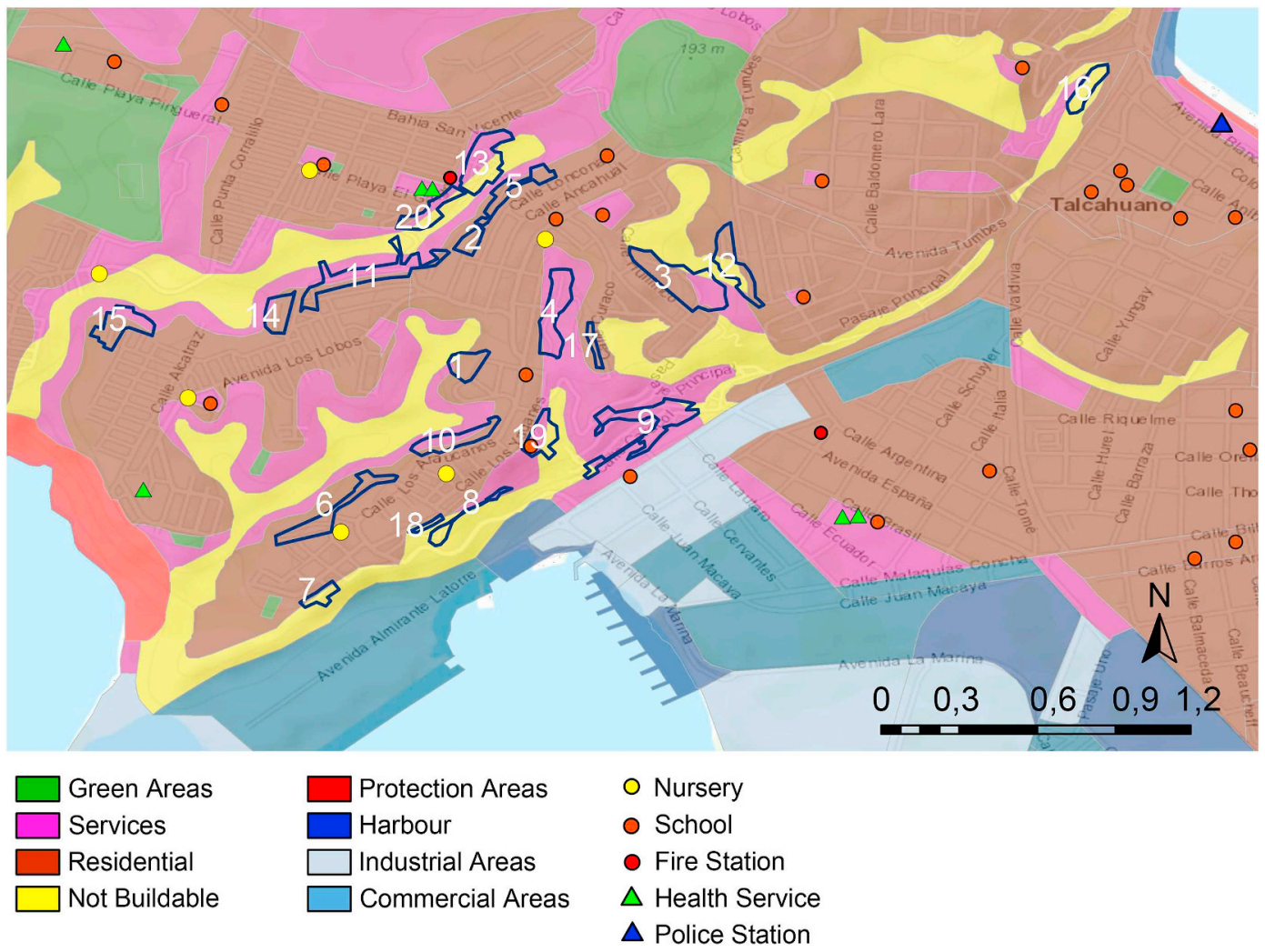

Fig. 4. Talcahuano Urban Regulation Plan and informal settlements. Source: Municipality of Talcahuano, Base-map: Topographic Maps Esri. 


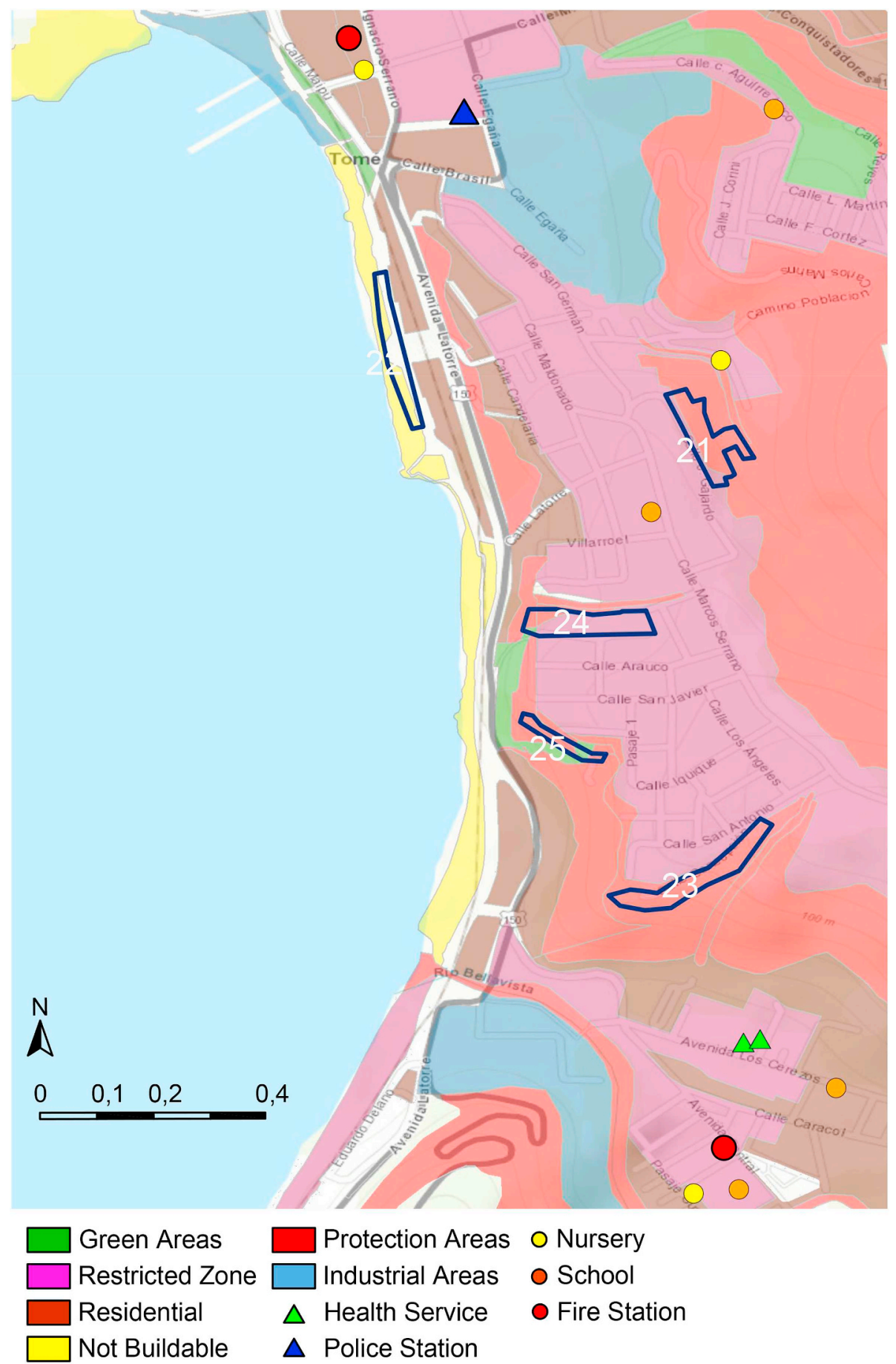

Fig. 5. Tomé Urban Regulation Plan and informal settlements. Source: Municipality of Tomé, Base-map: Topographic Maps Esri.

\section{Results and discussion}

After the identification of the campamentos in urban areas, data was collected according to the GOp framework and risk exposition. Figs. 2 and 3 show the urban area of Talcahuano and Tomé respectively, with the identification of campamentos (blue perimeter) and hazard exposition. Figs. 4 and 5 present the land use of Talcahuano and Tomé respectively, according to current urban plan (after post-disaster reconstruction). Table 2 provides information, employment sources (ES), hazard exposition and land use for each campamentos, while Table 4 shows the evaluation of services proximity indicators.

As showed in Figs. 2 and 3 and resumed in Table 2, all cases analysed are situated in risk areas, mainly on landslide areas, and only the case of Quinchito is in a tsunami flood area. This means that all families considered live in hazard conditions. Landslide is a risk that produces small but recurrent disasters, thus inhabitants are constantly exposed to the hazard of losing their houses. This result is also consistent with national data, according to which the $70 \%$ of families has settled in flooding areas and 34\% in landfill areas (MINVU, 2011).

The analysis of land use (Figs. 4 and 5) shows that the $70 \%$ of campamentos are settled in a non-building area such as a zone for environmental protection (ZNE and ZP) or areas for urban services (ZEXH6). There are some cases where the area is defined as "residential area", but in all cases, the urban regulation requires the application of 
Table 2

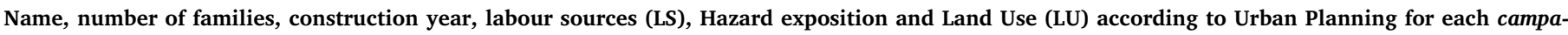
mentos settled in the cities of Talcahuano and Tomé.

$\begin{array}{ll}\text { ID } & \text { Name of Campamento } \\ \text { Talcahuano } & \\ 1 & \\ 2 & \text { Rucamanque Bajo } 8 \\ 3 & \text { Polcura } \\ 4 & \text { Huillinco Bajo } \\ 5 & \text { Antinao } \\ 6 & \text { Lonconao } \\ 7 & \text { Vista a la Bahia } \\ 8 & \text { Caramavida } \\ 9 & \text { Vista al Mar } \\ 10 & \text { La Union } \\ 11 & \text { Pasaje 1 La Gloria } \\ 12 & \text { Los Picunches } \\ 13 & \text { La Serena } \\ 14 & \text { Coliumo Alto } \\ 15 & \text { Las Gaviotas Bajo } \\ 16 & \text { Las Algas } \\ 17 & \text { Cerro Bagnara } \\ 18 & \text { Curaco } \\ 19 & \text { Monte Redondo } \\ 20 & \text { Las Hormiguitas } \\ & \text { Coliumo Bajo } \\ & \text { Total } \\ 21 & \text { Tomé } \\ 22 & \text { Pasaje Guajardo } \\ 23 & \text { Quichiuto - Estación } \\ 24 & \text { La Concepción } \\ 25 & \text { Quebrada Lawrence } \\ & \text { Samaritanos } \\ & \text { Total } \\ & \end{array}$

\begin{tabular}{|c|c|c|}
\hline N Families & Year & LS \\
\hline 64 & 1980 & Service \\
\hline 15 & 1980 & Service \\
\hline 14 & 1976 & Service \\
\hline 9 & 1986 & Service \\
\hline 34 & 1985 & Service \\
\hline 21 & 1960 & Industrial \\
\hline 14 & 1980 & Industrial \\
\hline 110 & 1970 & Industrial \\
\hline 90 & 1950 & Industrial \\
\hline 56 & 2002 & Industrial \\
\hline 12 & 1980 & Industrial \\
\hline 36 & 1995 & Service \\
\hline 32 & 1998 & Service \\
\hline 54 & 1995 & Service \\
\hline 87 & 1996 & Service \\
\hline 39 & 1955 & Harbour, commerce \\
\hline 9 & 1992 & Industrial \\
\hline 21 & 1960 & Industrial \\
\hline 20 & 2009 & Industrial \\
\hline 80 & 1960 & Service \\
\hline \multicolumn{3}{|l|}{817} \\
\hline 27 & 2005 & Service \\
\hline 38 & 1970 & Fishing \\
\hline 38 & 1985 & Service, Forestry \\
\hline 25 & 1985 & Service \\
\hline 55 & 2002 & Service \\
\hline
\end{tabular}
Hazard
Landslides
Landslides
Landslides
Landslides
Landslides
Landslides
Landslides
Landslides
Landslides
Landslides
Landslides
Landslides
Landslides
Landslides
Landslides
Landslides
Landslides
Landslides
Landslides
Landslides

LU

SERVICES

SERVICES

RESIDENTIAL

SERVICES

SERVICES

SERVICES

NOT BUILD.

NOT BUILD.

SERVICES

SERVICES

RESIDENTIAL

NOT BUILD.

NOT BUILD.

RESIDENTIAL

SERVICES

NOT BUILD.

SERVICES

NOT BUILD.

NOT BUILD.

NOT BUILD.

Table 3

Legend and interpretation of Land Use planning (Figs. 4 and 5). Source: Municipality of Talcahuano and Tomé.

$\begin{array}{lll}\text { Zoning } & \text { Definition } & \text { Rule } \\ \text { NOT BUILD. } & \begin{array}{l}\text { Zone not buildable } \\ \text { Spaces for urban services } \\ \text { and equipment }\end{array} & \begin{array}{l}\text { The construction is forbidden } \\ \text { Public spaces, commerce, sport } \\ \text { equipment, green areas }\end{array} \\ \text { RESIDENTIAL } & \begin{array}{l}\text { Residential area } \\ \text { Restricted zone for } \\ \text { RESTRICTED ZONE }\end{array} & \begin{array}{l}\text { Buildable index limited } \\ \text { Mitigation measured required }\end{array} \\ & \text { construction }\end{array}$

mitigation measurements in order to prevent natural risk exposition (see Table 3). The non-building areas and exposed areas have low or no value for the real estate market. Because of the Urban Planning upgrading during post-disaster reconstruction, the planning integrates the hazard exposition component. Due to the post-tsunami reconstruction programme, the two cities carried out comprehensive urban renovation work, which involved houses, urban spaces, amenities and infrastructures. Nevertheless, many households continue to live in exposed areas and in precarious conditions.

As regarding the access to work opportunity (Table 2), all settlements are strategically located in order to provide proximity to work centres or public transportation systems. The main job attractors in Talcahuano are the harbour and the industrial area located in the South-West of the Tumbes peninsula, as well as all services and commerce activities situated in the downtown. Concerning Tomé, the campamentos are located near the downtown, with good accessibility to productive and commercial centres. The case of Quinchito-Estación is also very interesting because the economic activity of campamentos inhabitants is linked with the sea: fishing, seafood collection, sale of fishery products and street food.

The analysis of service proximity indicators (Table 4) shows that the settlements have an advantageous location within the metropolitan area. Actually, all campamentos are close to Nursery and Primary

Schools (distance under $1 \mathrm{~km}$ ), more than the $75 \%$ of settlement has one Secondary School within $2 \mathrm{~km}$ and more than the $50 \%$ has one Health centre within $1 \mathrm{~km}$. Moreover, all campamentos are well connected with public transportation (bus or train). The recommended distances from Fireman station and Police station (these aspects are related to security and support during emergency after disaster), are satisfied by the $20 \%$ and $52 \%$ of settlements respectively.

From the analysis of our results, it is possible to individuate common patterns in settlement localisation that are related to neighbourhood opportunity. Proximity to labour sources and basic services (public transportation, educational and health) are the most relevant factors, while proximity to emergency and security services is not a driver for localisation.

The results also show that the poorest inhabitants are willing to accept exposure to risk in exchange for a strategic location within the city, namely the one that offers more opportunities. This suggests also the existence of a "normalisation of threat" factor, a process that should be studied in order to better understand its influence on informal settlements localisation.

This study also found that, despite the important steps forward in matters of risk management taken by signing the Hyogo Framework for Disaster Risk Reduction, local governments are generally unprepared to face urban vulnerabilities. The two case studies, Talcahuano and Tomé, are the best practice cases because they implemented a comprehensive reconstruction plan that involved city planning upgrading. In addition, the Talcahuano Municipality is the only one in Chile that has a Risk Management Office. Nonetheless, the two cities maintain a high number of informal settlements that could suffer severe damages in case of future adverse events.

\section{Conclusions}

In this paper we have sought to discuss the relation between urban informality and the social construction of hazard, because both topics are at the very top of the urban agenda. All the informal settlements 
Table 4

Results of data collected for the campamentos settled in the cities of Talcahuano and Tomé. Distances are expressed in $\mathrm{m}$ and Public transportation in number of lines. Source: Municipality of Talcahuano and Tomé, TECHO.

\begin{tabular}{|c|c|c|c|c|c|c|c|c|}
\hline Name of Campamento & Nursery (m) & Prim School (m) & Sec School (m) & Health (m) & Hospital (m) & Fireman (m) & Police (m) & Public transport (n) \\
\hline \multicolumn{9}{|l|}{ Talcahuano } \\
\hline Rucamanque Bajo 8 & 356 & 320 & 2044 & 1436 & 3618 & 7977 & 2434 & 4 \\
\hline Polcura & 196 & 315 & 3530 & 1294 & 3530 & 7983 & 2179 & 4 \\
\hline Huilllinco Bajo & 373 & 300 & 1254 & 839 & 3102 & 7683 & 1638 & 4 \\
\hline Antinao & 175 & 254 & 1566 & 1008 & 3254 & 7746 & 1950 & 4 \\
\hline Lonconao & 164 & 220 & 1684 & 1320 & 3577 & 8078 & 2086 & 4 \\
\hline Vista a la Bahia & 67 & 451 & 2316 & 1318 & 3195 & 7335 & 2655 & 7 \\
\hline Caramavida & 205 & 662 & 2452 & 1366 & 3069 & 7110 & 2770 & 7 \\
\hline Vista al Mar & 160 & 714 & 2051 & 1006 & 2924 & 7171 & 2374 & 8 \\
\hline La Union & 502 & 562 & 1508 & 591 & 2785 & 7263 & 1840 & 2 \\
\hline Pasaje 1 La Gloria & 108 & 611 & 1942 & 1033 & 3100 & 7417 & 2292 & 8 \\
\hline Los Picunches & 344 & 550 & 1841 & 1080 & 3241 & 7621 & 2211 & 4 \\
\hline La Serena & 478 & 216 & 1122 & 838 & 3087 & 7705 & 1511 & 7 \\
\hline Coliumo Alto & 284 & 311 & 1847 & 124 & 3664 & 8118 & 2158 & 7 \\
\hline Las Gaviotas Bajo & 348 & 318 & 2277 & 1578 & 7840 & 7955 & 2663 & 4 \\
\hline Las Algas & 192 & 305 & 2631 & 1894 & 7953 & 8070 & 3017 & 4 \\
\hline Cerro Bagnara & 969 & 167 & 463 & 1450 & 3274 & 8045 & 795 & 9, Railway \\
\hline Curaco & 346 & 398 & 1547 & 862 & 3093 & 7574 & 1916 & 4 \\
\hline Monte Redondo & 140 & 626 & 2205 & 1157 & 3012 & 7187 & 2431 & 8 \\
\hline Las Hormiguitas & 266 & 712 & 1735 & 807 & 2925 & 7319 & 2075 & 2 \\
\hline Coliumo Bajo & 260 & 301 & 1846 & 120 & 3365 & 8188 & 2278 & 7 \\
\hline \multicolumn{9}{|l|}{ Tomé } \\
\hline Pasaje Guajardo & 137 & 187 & 986 & 938 & 938 & 1124 & 777 & 2 \\
\hline Quichiuto - Estación & 439 & 561 & 867 & 984 & 984 & 1246 & 511 & 7 \\
\hline La Concepción & 542 & 539 & 2034 & 1725 & 1725 & 519 & 1535 & 2 \\
\hline Quebrada Lawrence & 502 & 217 & 1551 & 1302 & 1302 & 994 & 1050 & 7 \\
\hline Samaritanos & 707 & 422 & 1742 & 1507 & 1507 & 807 & 1239 & 7 \\
\hline
\end{tabular}

used as case studies are located into the metropolitan area and exposed to natural risk. These conditions are representative of most of the informal settlements in Chile. We have also considered the reasons behind this issue by understanding how place contributes to the satisfaction of personal and communitarian needs and aspirations.

The consideration of case studies results confirms that it is possible to identify the drivers for the localisation of informal settlements into urban areas through the GOp approach. According to the data, neighbourhood opportunity and perceived opportunities influence household decision-making process for the localisation within the metropolitan area. On the other hand, the risk exposition does not affect the location selection for informal settlements. All cases analysed are located on hazard-exposed areas. As a consequence, most slum inhabitants are exposed to recurrent disasters such as landslides, flooding or fire. ${ }^{2}$ These risks could be mitigated by adopting appropriate and expensive countermeasures but informal settlements inhabitants cannot afford such expenses.

Therefore, we may conclude that the first aspiration for poor inhabitants is home ownership with good location, well connected with employment sources and basic services. This means that the problem does not lie in the housing provision but in finding housing with good location into the metropolitan area. Because of the fact that social housing is located in suburban areas, the poor can satisfy their need of neighbourhood opportunity only by occupying residual spaces near downtown, which are hazard-exposed areas.

These findings cast doubts over the effectiveness of institutional action for informality eradication in Chile. The urban informality-eradication programmes adopted over the last three decades produced negative results, as evidenced by the increment of informal dwellings in the lasts years. The housing deficit policy, which only focuses on

\footnotetext{
${ }^{2}$ Most informal settlements in Chile are exposed to fire risk due to materials flammability (mainly wood, paperboard, plastic and aluminium) used to build houses and the precariousness of technical systems (especially electrical system). This hazard exposition is clearly due to the low economic capacity of such households.
}

accomplishing the quantitative target, do not satisfy household needs in relation to location within the metropolitan area. The current policy, based on the support neoliberal model, encourages the real estate exploitation and the localisation of social housing neighbourhoods in suburban areas. Currently, social housing inhabitants, located in deprived and unconnected neighbourhoods, have limited capacity to satisfy their needs and find resources to improve their situation. Compared to these neighbourhoods, the campamentos offer better neighbourhood opportunities. Hence we may infer that the current social housing policy is one of the causes for informality re-production in Chilean cities. This is due to two factors: on the one hand, the neoliberal model promotes spatial segregation and inequalities; on the other hand, the institutional action did not consider hazard exposition as a factor that makes urban vulnerability worse, e.g. due to exposition to recurrent disasters, such as landslides.

In the light of these findings, we would like to emphasise that the current housing deficit policies should be oriented to rebalance spatial inequality, through consideration of the needs of the poor in relation to localisation. This is achievable by following GOp viewpoint. Furthermore, urban poverty eradication initiatives should integrate natural disaster prevention among the aspects involved in decisionmaking processes. Indeed, the existent informality reduction programmes do not pay special attention to settlements exposed to natural threats, neither they provide solutions for the mitigation of frequent disasters. At the same time, risk reduction management initiatives should adopt a multisector view of vulnerability, involving issues as urban poverty, social inequality and housing policy in addition to aspects related to pure hazard exposition.

\section{Acknowledgements}

The authors would like to thank TECHO PARA CHILE Foundation for providing updated data collected in the "Catastro de Campamentos 2016" elaborated by the same Foundation. 


\section{References}

Argüello-Rodriguez, M. (2004). Riesgo, vivienda y arquitectura. Conferencia En El Congreso ARQUISUR, Universidad de San Juan, Argentina (pp. 1-18). .

Arouri, M., Nguyen, C., \& Youssef, A. B. (2015). Natural disasters, household welfare, and resilience: Evidence from rural vietnam. World Development, 70, 59-77. https://doi. org/10.1016/j.worlddev.2014.12.017.

Bankoff, G. (2004). In the eye of the storm: The social construction of the forces of nature and the climatic and seismic construction of god in the Philippines. Journal of Southeast Asian Studies, 35, 91-111. https://doi.org/10.1017/S0022463404000050 February.

Bankoff, G. (2007). Comparing vulnerabilities: Toward charting an historical trajectory of disasters. Historical Social Research, 32(3), 103-114. https://doi.org/10.2307/ 20762224.

Beytía, P., \& Correa, J. (2013). Actualización del Catastro Nacional de Campamentos. Retrieved from https://issuu.com/techochile/docs/act_catastro/3?e=6000687/ 5844009.

Birkmann, J. (2006). In J. Birkmann (Ed.). The energy). .

Brooks, N. (2003). Vulnerability ,risk and adaptation: A conceptual framework. Tyndall Centre for Climate Change Research, 38(November), 20. Retrieved from papers2 http://publication/uuid/D2016620-F4DE-4C0A-BE4B-78E8F2701438.

Cardona, O. D. (2003). The need for rethinking the concepts of vulnerability and risk from a holistic Perspective: A necessary review and criticism for effective. Mapping vulnerability: Disasters, development and people (pp. 37-51). . https://doi.org/10.4324/ 9781849771924 (Chapter 3).

Castillo-Couve, M. J. (2012). Producción y gestión habitacional de los plobadores. Directoriodigital.Com. Universidad Politécnica de Madrid. Retrieved from http:// www.directoriodigital.com/empresas/agfoliares/PROYECTO_ZEOLITA_2006.pdf.

Castro García, C. (2005). La inequidad de género en la gestión integral del riesgo de desastre. Un acercamiento. 1 Cecilia Castro García*. Revista de La Universidad Cristóbal Colón, 20, 1-28.

Castro, C. P., Ibarra, I., Lukas, M., Ortiz, J., \& Sarmiento, J. P. (2015). Disaster risk construction in the progressive consolidation of informal settlements: Iquique and Puerto Montt (Chile) case studies. International Journal of Disaster Risk Reduction, 13, 109-127. https://doi.org/10.1016/j.ijdrr.2015.05.001.

Ciurean, R., Schröter, D., \& Glade, T. (2013). Conceptual frameworks of vulnerability assessments for natural disasters reduction. Approaches to disaster management examining the implications of hazards. Emergencies and Disasters, 3-32. https://doi. org/10.5772/55538.

Cutter, S. L., Boruff, B. J., \& Shirley, W. L. (2003). Social vulnerability to environmental hazards. Social Science Quarterly, 84(2), 242-261. https://doi.org/10.1111/15406237.8402002 .

Fernandes, E. (2011). Regularization of informal settlements in Latin America. MA: Lincoln Institute of Land Policy. Retrieved from http://www.lincolninst.edu/pubs/1906 Regularization-of-Informal-Settlements-in-Latin-America.

Galster, G. C., \& Killen, S. P. (1995). The geography of metropolitan opportunity: A reconnaissance and conceptual framework. Housing Policy Debate, 6(1), 7-43. https:// doi.org/10.1080/10511482.1995.9521180.

Gesto, B. (2015). Los programas municipales de ocupación guiada: instrumentos preferentes de habitabilidad básica. Universidad Politécnica de Madrid.

Gilbert, A. (2004). Helping the poor through housing subsidies: Lessons from Chile, Columbia and South Africa. Habitat International, 28(1), 13-40. https://doi.org/10. 1016/S0197-3975(02)00070-X.

IPCC (2014). Summary for policymakers. Cambridge university pres (Ed.), climate change 2014: Impacts, adaptation and vulnerability - contributions of the working group II to the fifth assessment Report (pp. 1-32). . https://doi.org/10.1016/j.renene.2009.11.012 Cambridge.

MINVU (2011). Catastro 2011 : Mapa Social de Campamentos Resultados Generales.

Miranda Sara, L., Jameson, S., Pfeffer, K., \& Baud, I. (2016). Risk perception: The social construction of spatial knowledge around climate change-related scenarios in Lima. Habitat International, 54, 136-149. https://doi.org/10.1016/j.habitatint.2015.12. 025 .

Olivera, a., \& González, G. (2010). Enfoque multidimensional de la reconstrucción postdesastre de la vivienda social y el hábitat en países en vías de desarrollo: Estudios de casos en Cuba. Revista de La Construccion, 9(2), 53-62. https://doi.org/10.4067/ S0718-915X2010000200006.

Olthuis, K., Benni, J., Eichwede, K., \& Zevenbergen, C. (2015). Slum Upgrading: Assessing the importance of location and a plea for a spatial approach. Habitat International, 50, 270-288. https://doi.org/10.1016/j.habitatint.2015.08.033.

Osypuk, T. L., \& Acevedo-Garcia, D. (2010). Beyond individual neighborhoods: A geography of opportunity perspective for understanding racial/ethnic health disparities. Health \& Place, 16(6), 1113-1123. https://doi.org/10.1016/j.healthplace.2010.07. 002.

Perea Moreno, L. (2015). Hacia un análisis cuantitativo de la Ciudad Informal. UNIVERSIDAD POLITÉCNICA DE MADRID. Retrieved from http://oa.upm.es/ 39873/.

Pérez-Iñigo González, A. (1999). El factor institucional en los resultados y desafíos de la política de vivienda de interés social en Chile. Retrieved from http://repositorio.cepal. org/handle/11362/5285.

Rodríguez, A. (1990). Desastres urbanos, fenómenos no-naturales. Revista medio ambiente y urbanización: desastres y vulnerabilidad en América Latina.

Rodriguez, A., \& Sugranyes, A. (2004). El problema de la vivienda de los "con techo. Eure 30(91), 53-65.

Roy, A. (2011). Slumdog cities: Rethinking subaltern urbanism. International Journal of Urban and Regional Research, 35(2), 223-238. https://doi.org/10.1111/j.1468-2427. 2011.01051.x.

Sawada, Y., \& Takasaki, Y. (2017). Natural disaster, poverty, and development. World Development, 94, 1. https://doi.org/10.1016/j.worlddev.2016.12.045.

Soyinka, O., \& Siu, K. W. M. (2018). Urban informality, housing insecurity, and social exclusion; concept and case study assessment for sustainable urban development. City: Culture and Societyhttps://doi.org/10.1016/j.ccs.2018.03.005 April 2017.

UNISDR (2004). Living with risk: A global review of disaster reduction initiatives. Strategy, 19211010640.

UNISDR (2015). Sendai framework for disaster risk reduction 2015-2030. Geneva. Retrieved from www.unisdr.com.

Winsemius, H. C., Jongman, B., Veldkamp, T. I. E., Hallegatte, S., Bangalore, M., \& Ward, P. J. (2018). Disaster risk, climate change, and poverty: Assessing the global exposure of poor people to floods and droughts. https://doi.org/10.1017/S1355770X17000444. 